\title{
The Power of Electronic Video Recording Proof in Crime Possession of Sharp Weapons
}

\author{
SYAWAL ABDULAJID
}

\begin{abstract}
The study of "The Power of Electronic Video Recording Proof in Crime Possession of Sharp Weapons" focused on the power of electronic video recording proof. The aims of this study are to know the process of cases examination in Ternate District Court associated with the crime possession of sharp weapons namely video recording proof presented as evidence, and how the validity of video evidence as evidence and has the power of proof in the trial. This type of research is normative-empirical and uses secondary data as the main reference in analyzing data, the authors use qualitative descriptive analysis techniques that are based on applicable regulations and then adjusted to the reality that occurred in the field. Furthermore, in conclusion is done with deductive method that is analysis conducted with general knowledge to conclude things specifics. The results of the study showed that the proof of recording used as evidence in the crime possession of sharp weapons clearly not in accordance with criminal law procedure code (KUHAP), in the proving of crime possession of sharp weapons refer to Article 184 of KUHAP regarding legal evidence so that the evidence of the video recording is in principle merely as exhibit and cannot be used as evidence on the offense. Concerning the evidence presented in the hearing is the legally obtained evidence that is in accordance with applicable laws and regulations so that the proof has the evidentiary power to determine the defendant's faults. In the case number: 286/Pid/2016/ Pn.Tte, and 279/Pid/2016/Pn.Tte, the recorded evidence presented is evidence obtained from the public then copied by the investigator and copied on the CD-R, so the opinion of the prosecutor as in his claim stating the guilt of the defendants has been proven legally and convincingly based on the evidence of the video recording is a mistake and undermines the basic principles of procedural law.
\end{abstract}

Keywords: Electronic video recording; criminal procedure; proof; Crime Possession of Sharp Weapons

\section{INTRODUCTION}

\section{BACKGROUND}

Law is a tool to regulate society as a means of social control, the law is in charge of keeping people in the patterns of behavior accepted by them. While the purpose of the law itself is expected to provide justice, certainty, and benefit for the community.

Evidence is the most decisive stage in the trial process, considering that at the stage of proof will be determined whether or not a defendant committed a criminal act as prosecutor indicted. Proof of whether or not the defendant has committed the alleged offense is the most important part of the criminal procedure law. It cannot be denied that even though the law has been present in the community, there is still an act that is contrary to the law.

According to Subekti in Rusli Muhamad's book on the Indonesian criminal justice system, the judicial system is an orderly arrangement, a whole consisting of parts related to each other, arranged as a plan or pattern, the result of a thought to achieve the goal. In a good system there can be no conflict or clash between the parts, nor there a duplication or overlapping between the parts. ${ }^{1}$

The development of science and technology also affect the system of law enforcement, so that in law enforcement is required to keep up the technological progress, one example of close circuit television (CCTV) or amateur video recordings that are considered more facilitate in exposing a crime in the current criminal acts.

In connection with the results of electronic records that serve as evidence against the case in question originated from the brawl between Toboko Sub-District and Mangga Dua Sub-District, of the incident was carried out the development and found 
video recordings of one of the residents who contain activities of making wayar arrows and spears that allegedly used for brawl between residents.

Based on the recording, the arrest of the three perpetrators are Ikram Ismail aka Ikram, M. Amran Umagapi aka Nan, and Marlan Dimara aka Om Ambon. Furthermore, the results of the developments are foreclosure of evidence in the form of wayar arrows, along with the equipment used to make them.

Based on the evidence collected, the three defendants are jointly prosecuted or allied or with their respective roles "conducting, committing, and participating in an act of non-exclusive rights to Indonesia, making, receiving, modifying it, submitting, or attempting to submit, control, carry, stock or own, store, transport, hide, use, or remove or expel from Indonesia a hammer weapon, stabbing weapons, or piercing weapons" as regulated and criminalized in Article 2 Paragraph (1) of the Emergency Law Number 12 Year 1951 Jo Article 55 Paragraph (1) to-1 of the Penal Code (KUHP).

\section{ISSUES FORMULATION}

After describing the things contained above, thus the author will formulate the problem as follows:

1. Whether the video recordings are used as evidence in the verification in a court hearing in a crime?

2. How does a video record have a proof value in court?

\section{RESEARCH OBJECTIVES}

The objectives to be achieved in this research is:

1. To find out whether the video recordings are used as evidence in the verification in a court hearing in a crime.

2. To find out how does a video record have a proof value in court.

\section{LITERATURE REVIEW}

\section{DEFINITON OF CRIMINAL LAW PROCEDURE}

Criminal law procedure as formal law and serve as guidance of the implementation of material criminal law covers about procedure and implementation to maintain of material criminal law. In the KUHP does not define what constitutes a criminal law procedure. But the definition of procedural law put forward by some experts as follows:

According to $\mathrm{R}$. Soeroso that the procedural law is some set of provisions with the aim of providing guidance in the search for truth and justice in case of violation of legal provisions in material law which means giving the law of the event a relationship that serves the material law. Andi Sofyan ${ }^{2}$ (2014:3) explain the procedural law as a guide for seeking truth and justice. The word of the violation referred to in the above sense is the offense of the law, an act against the law or which is prohibited by law itself, aims to serve the meaning of maintaining material law.

According to Moeljatno, the procedural law is a law that regulates the procedures for the execution of material law, and criminal law procedure is a law that regulates how to implement/maintain the material criminal law.

\section{FUNCTION OF CRIMINAL LAW PROCEDURE}

The above description has been mentioned if the criminal law is divided into two types namely the formal criminal law and the material criminal law. The material criminal law determines what actions can be convicted, who can be convicted, and 
what criminal can be imposed. While the formal criminal law as the implementation of the material criminal law that regulates how the state by using its tools to be able to penalize or exempt the punishment.

In realizing the authority already mentioned, there are two kinds of interests that demand to the state instrument namely: ${ }^{3}$

1. General interest, a person who violates a criminal law must have a criminal penalty for his guilt in order to maintain public security.

2. The interest of the person charged with, that the law of the person charged with the matter shall be treated honestly and fairly, that it shall be preserved not to have an innocent person convicted, or if he is guilty, lest he gain injustice

\section{CRIMINAL LAW PROCEDURE OBJECTIVES}

Criminal law procedure as already formulated in the guideline of the KUHAP, that the criminal law procedure objectives as follows:

1. Seeking and obtaining, or at least approaching material truth is the complete truth of a criminal case by applying the criminal procedural provisions honestly and appropriately.

2. Seeking who the perpetrator could be charged with violates the law and subsequently requests the examination and decision of the court to determine whether a criminal offense has been committed, and whether the accused person is to be blamed.

3. After the court judgment has been imposed, all legal efforts have been carried out and finally the decision has a permanent legal force, then the criminal law procedure also regulates the principal of implementation and supervision of the decision

Based on the description, it can be concluded that the criminal law procedure is a legal rule of criminal law enforcement from the process of investigation, investigation, prosecution, judiciary to the execution of the verdict.

Consideration of the letter $\mathrm{c}$ of KUHAP which is the foundation or lines of objectives to be achieved by KUHAP "That the development of such a national law in the field of criminal law procedure is so that the public will live their rights and obligations and to enhance the guidance of law enforcement officers in accordance with their respective functions and authorities towards the establishment of law, justice, and protection of human dignity, order and legal certainty for the implementation of the state of law in accordance with the 1945 Constitution.

Thus, on the one hand the State has an interest in protecting public order and the rights of citizens from acts and violations of the law committed by the person who committed the offense. On the other hand, in enforcing the law of the State shall not engage in acts and measures that are prohibited by law, in order to guarantee legal protection to every citizen.

\section{DEFINITION OF INITIAL INVESTIGATION}

Initial investigation is the first stage of handling criminal cases by initial police investigators who know, or get reports or complaints from the public, about been or are currently or expected events that allegedly constitute a criminal offense. From the results of such reporting or complaint, the initial police investigators then make a preliminary review of the reported case whether it is within the scope of the criminal law or not and if it falls within the scope of the criminal law is it normal to conduct an investigation.

Initial police investigators in KUHAP Article 1, number 3 are: the police 
of the Republic of Indonesia authorized by the Act to conduct an initial investigation. The initial police investigators in conducting the investigation has the authority to receive reports, to seek information and evidence, to stop the suspect, and to initial investigation and to check the identity of the person, then to take other action according to the law responsible. Based on Article 16 paragraph (1) of KUHAP, for the sake of investigation, initial police investigators on the orders of investigators may make arrests. However, in order to guarantee the suspect's human rights, the arrest order must be based on sufficient initial evidence.

\section{INVESTIGATION}

Investigation is a term intended to be parallel to understanding Opsporing (Dutch) and Investigation (English) or tactics (Malay).

Investigation in KUHAP Article 1 point 2 is a series of investigative actions in respect of and in the manner provided for in this law to seek and collect evidence thereby making clear on the offense and finding the suspect. Provided with the authority to conduct investigations in Article 1 point 1 are officials of the Indonesian National Police, and certain Civil Service Officials who are given special authority by the Act to conduct an investigation.

The investigation was preceded by a notice to the public prosecutor that an investigation of a criminal incident had already begun. Formally notification is submitted through the mechanism of Investigation Commencement Notice (SPDP)

The stage of initial investigation emphasis is placed on the act of "seeking and finding" an event that is considered or suspected to be a criminal offense. While in the investigation the emphasis is placed on the act of "seeking and gathering evidence" and with such evidence makes clear about criminal events, and determines who the suspects. Furthermore, in Article 1 point 14 of KUHAP, the Suspect is a person who due to his actions or circumstances, based on preliminary evidence suspected to be the perpetrator of a criminal offense. As in the Decision of the Constitutional Court Number 21/PUUXII / 2015 affirming sufficient initial evidence are two evidences as referred to in Article 184 of KUHAP. Thus, it can be concluded that sufficient preliminary evidence is classified into two categories namely is a condition to conduct an investigation, and determine the status of the suspect to a person suspected of having committed a crime, and whether the suspect can be brought before the court as a defendant (Chandra M Hamzah, 2014:6).

\section{VERIFICATION}

The definition of "verification" in general is the provisions which contain lines and guidelines on law-justified ways of proving wrongs indicted to defendants. Evidence is also a provision that regulates the evidence substantiated by law and may be used by a judge to prove the guilt of the indictment. Furthermore, the word proves to have the meaning of showing evidence, and/or convincing by proof.

Regarding the meaning of verification can be found in the opinions of experts, among others:

R. Subekti, states that: "To prove" is to convince the judge of the truth of the arguments presented in a dispute. According to $\mathrm{R}$. Subekti proves is to convince the judge, this is certainly if what he meant by the proof in the court. The beginning of the initial investigation in which the evidence indicates the belief that a crime has been committed.

According to J.C.T. Simorangkir, et al., that the proof is the business of the authorities to bring to the judge as much as possible matters relating to a case which aims to be used by the judge as the material 
for decision making in the case. Thus, the verification according to J.C.T Simorangkir, et.al., is the effort to collect the evidence as much as possible, before the examination in court which aims as the reason for the judge to make a decision.

In KUHAP seeks and collects evidence already commenced at the time of investigation as contained in Article 5 paragraph (1), letter a point 2 the initial police investigator is obliged and has the authority to seek information and evidence, aiming to determine whether the investigated event is a criminal offense, then what is the usual investigation. In the investigation, seek and collect evidence to find and assign a person as a suspect, and whether the suspect can be brought to trial. In the prosecution proceedings, the evidence that has been collected aims to convince a judge in imposing a penalty on a defendant.

The definition of exhibit in general has a very broad meaning, thus the author will try to describe the definition of exhibit according to experts, and contained in the legislation.

1. According to Ansori Hasibuan, exhibit is the goods used by the defendant in committing an offense, or goods as a result of a crime.

2. Meanwhile, according to Andi Hamzah the exhibit is the goods about the offense is done (object), and the goods with the offense is done that is the tool used to do the offense.

3. In a large dictionary of Indonesian language (KBBI) also mentioned the sense of evidence that is the object used to convince the judge of the defendant's mistake of criminal cases alleged to him.

According to Martiman Prodjohamidjojo, evidence or corpus delicti is exhibit of crime. In Article 181 of KUHAP the judges shall show the defendant all the exhibit and ask him whether he recognizes the exhibit. If deemed necessary, the judge shall show the exhibit. Ansori Hasibuan believes that the exhibit is the goods used by the defendant to commit an offense or as a result of a crime, seized by the investigator to be used as court exhibit. (Ansori Hasibuan, Op.Cit.)

The exhibit that has been obtained can then be used in evidence in court to convince the judge of the crime committed by the defendant.

1. Testimony of the witness, in Article 1 number 27 of KUHAP is an evidence in a criminal case in the form of testimony from witness concerning a criminal event which he hears personally, and he experienced his own by calling the reason of his knowledge. According to the provisions of Article 185 paragraph (1) of KUHAP, it provides a definition of witness statements in their capacity as evidence, is "the testimony of the witness as evidence is what the witness stated in court" (C. Djisman Samosir, 2013:129).

2. Expert's testimony is science that has been learned (owned). Definition of science (wetenschap) expanded his understanding by Hoge Raad which includes criminalism. Science, archeology, knowledge of fingerprints, belong to the category of wetenschap classification. Therefore, an expert can be heard his statement on a particular matter which the judge considers the person to know the field in particular.

3. Letter as evidence (Article 187 KUHAP), as referred to in Article 184 paragraph (1) letter c, made on oath of office or reinforced by oath. 


\section{RESEARCH METHOD}

\section{TYPE OF RESEARCH}

This type of research is a normativeempirical legal research, i.e. research by analyzing the provisions of the law and then adjust/compare the reality that happened to the case law, i.e. analyzing Case Number: 286/Pid/2016/Pn.Tte, and Case Number: 279/Pid/ 2016/Pn.Tte related to the evidence of amateur video recordings used as electronic evidence in criminal cases related to Emergency Law No. 12 Year 1951 Jo Article 55 Paragraph (1) point 1 of KUHP.

\section{RESEARCH SITES}

The research location will be conducted in Ternate District Court as a place to obtain data and information related to Case Number: 286/Pid/2016/Pn.Tte, and Case Number: 279/Pid/2016/Pn.Tte which is being handled by the Legal Counsel of the North Maluku Legal Aid Foundation.

\section{TYPES AND DATA SOURCES}

\section{Type of Data}

The type of data used in this study is (Soejono and Abdurahman 2003:56):

a. Primary data, the original or preliminary data that the author obtained directly from the source.

b. Secondary data, is the primary data support.

2. Data Source

Source of data in this research is divided into two, namely:

a. Primary data sources are derived from the results of research conducted in the courts namely, interviews with prosecutors and defense counsel of the defendants. This is done to find out the grounds used by the prosecutor in the case of filing evidence of electronic records as evidence, and the basis of the objection from the defense counsel of the defendants denied the evidence of electronic records as evidence in a court.

b. Secondary data sources, consisting of various analyzes of literature study results. Secondary data is sourced from:

i. Primary Legal Material: Legislation.

ii. Secondary Law Material: Books, literature, and so forth.

iii. Tertiary Law Material: Indonesian Dictionary.

\section{DATA COLLECTION TECHNIQUE}

Data collection techniques is the most strategic step in the research, because the main purpose of the research is to get the data. Without knowing the techniques of data collection, the research will not get data that meets the specified standards. ${ }^{4}$ Data collection techniques that the authors use in this study is:

a. Field Study

Data collection by conducting interviews is intended to obtain information about the data that are needed directly that can support/complement to answer this problem. Interviews were conducted by holding questions directly with the Public Prosecutor and Legal Counsel of the defendants, related to the issues being investigated, as well as interviews to some jurists who have the ability to interpret the formulation of evidence.

b. Library Studies

Literature study, the author uses by way of recording materials or data obtained through various literature by experts in the form of scientific knowledge, or understanding of issues related issues in books, research reports, thesis, dissertation 
and other related issues with the problem being studied.

\section{DATA ANALYSIS TECHNIQUE}

Data analysis techniques that the authors use to produce accurate conclusions and achieve the scientific truth, then the material that has been obtained through the writer interview and literature study, then processed and analyzed qualitatively by using deductive method.

The deductive method in question is a form of data analysis with the starting point of things that are general, then summed up in a special case. This method is used to explain the position of electronic record evidence as evidence in general criminal acts.

\section{RESULTS AND DISCUSSION}

\section{VIDEO RECORDING AS EVIDENCE IN CRIMINAL CASE SESSION}

Evidence in criminal law procedure is a process in law enforcement to know whether the event is a crime, then whether can be done investigation to determine who the suspect. If the suspect has been obtained then the next stage of handling the suspect along with the evidence that has been collected to the General Prosecutor (JPU) then the case is heard and examined in court.

The evidence gathered at the initial investigation and investigation level is then tested at the trial whether the evidence has been obtained legally, and then whether the evidence has a verifying power in court to prove the defendant's wrongdoing. The judge must be careful in dropping the punishment decision against the defendant, judging the evidences carefully. Proof is a provision containing guidelines on justified ways in law to prove the defendant's accused $^{5}$. The evidentiary system in Indonesia recognizes there are several theories about the proof that is:

\section{a. Conviction in Raisone}

The doctrine of proof is based on the judge's conviction. The judge remains independent of the evidence set out in the law. Although the evidence has been established by law, but the judge may use outside evidence as prescribed by law. However, in making a decision about whether or not a defendant should be based on a clear reason. So, the judge must base his decision on a defendant on the reasoning. Therefore, the ruling is also based on reasons that are reasonable. The judge's conviction must be based on a logical and acceptable reason and reason, not solely based on unlimited faith. This evidentiary system is often referred to as a free verification system.

\section{b. Positive Evidentiary System}

Positive evidentiary system (positief wettelijk) is a system of evidence based on evidence only, i.e. evidence which has been determined by law. A defendant may be found guilty of committing a criminal offense based only on valid evidence. The evidence provided by the law is important. The judge's conviction was completely ignored. In essence, if a defendant has fulfilled the validation and legal evidences set by the law, the defendant may be found guilty and shall be convicted. A judge like a robot who runs the law. However, there is good in this evidentiary system that the judge will try to prove the defendant's wrongdoing without being influenced by his conscience so that it is completely objective. That is according to the means and evidence as prescribed by law. The system of positive proof sought is 
formal truth, therefore this evidentiary system is used in civil law procedure. ${ }^{6}$

c. Negative Evidentiary System Negative verification system (negatief wettelijk) is very similar to the conviction in raisone system. The judge in making a decision about whether or not a defendant is bound by the evidence determined by the judge's own laws and convictions. So in the negative system there are 2 things which is a condition to prove the defendant's fault, that is:

i. The existence of legal evidences established by law.

ii. The existence of the judge's (conscience) conviction that is based on the evidence the judge believes the defendant's wrongdoing. The evidence which has been determined by the law cannot be supplemented by other evidence, and based on evidence presented in court as prescribed by law cannot force a judge to say the defendant has committed a crime charged.

The evidentiary system in Indonesia uses a negative evidentiary system as in Article 183 of KUHAP that the judge shall not impose a penalty on a person, except with at least two valid evidences and the belief that a crime is actually taking place, and that the defendant is guilty of doing so.

The KUHAP itself limits the legal evidence as in Article 184 of KUHAP:

1. Witness' testimony

2. Expert's testimony

3. Letter

4. Indication

5. Defendant' testimony
As for the evidence as referred to in Article 39 paragraph (1) of KUHAP:

a. Any object or bill of a suspect or defendant wholly or partly allegedly obtained from a crime, or as a result of a criminal offense.

b. Objects that have been used directly to commit a crime, or to prepare it.

c. Objects used to obstruct criminal investigations.

d. Other objects that have a direct relationship with the crime committed.

Furthermore, according to the police regulations of the Republic of Indonesia Number 12 Year 2009 on the supervision and control of criminal cases handling in the Police article 116 that is:

(1) Evidence seized is an object suspected to have anything to do with a criminal case under initial investigation and may be used as a supporter of evidence in a court proceeding.

(2) The types of evidence that can be seized, among others:

a. objects or bills of suspects/defendants suspected of a crime or as a result of a crime;

b. objects that have been used directly to commit or prepare for a crime;

c. objects used to obstruct investigations;

d. special objects made or intended to commit a crime; and

e. other objects (including optical fibers) that have a direct relationship to the crime committed. 
KUHAP limits legal evidence, limited to witness' testimony, expert's testimony, letter, indication, defendant' testimony. As for the evidence of video recording mentioned in the Regulation of the Chief of Police of the Republic of Indonesia No. 12 Year 2009, Article 116 paragraph (2) letter d, other objects (including optical fiber) which have a direct relationship with the crime. Accordingly, the recording video may be used in proof but only as exhibit.

Information stored electronically, including records, cannot be submitted as evidence under the KUHAP. KUHAP also does not govern how the legality of electronic evidence as evidence or procedure for the acquisition and submission of electronic information as evidence.

New information or electronic documents are recognized as evidence after the enactment of Law No. 20 Year 2001 on the Eradication of Corruption (Law No. 20/2001). Article 26 A Law No. 20/2001 states that evidence stored electronically can also be used as legal evidence in cases of corruption.

In addition to Law No. 20/2001, electronic information as evidence is also mentioned in Article 38 letter b Law No. 15 Year 2002 on the Crime of Money Laundering (Law No.15/2002), and 27 letter b Law No. 15 Year 2003 on Combating Terrorism Crime (Law No. 15/2003).

Although Law No. 20/2001, Law No. 15/2002 and Law No. 15/2003 has acknowledged the legality of electronic information as evidence, but its validity is still limited to criminal acts in the sphere of corruption, money laundering and terrorism.

In Law No. 20/2001, Law No. $15 / 2002$ and Law No. 15/2003 there is also no clarity on the legality of electronic evidence as evidence. There is also no set of procedures that can be a reference in the acquisition and submission of information or electronic documents as evidence to the court.

The legal basis for the use of information or electronic documents as evidence in court becomes clearer after the enactment of Law No. 11 Year 2008 which has been amended by Law Number 19 Year 2016 on Information and Electronic Transactions (Law No. 19/2016). Law No. $19 / 2016$ is considered to provide greater legal certainty and the extent of its enforcement, not limited to corruption, money laundering and terrorism.

Article 5 paragraph (1) of Law No. 19/2016 stating that electronic information and/or electronic documents and/or prints are legal evidence. Furthermore, Electronic information and/or Electronic Document shall be declared valid if using Electronic System fulfilling the minimum requirements as meant in Article 5 paragraph (3) jo. Article 6 of Law No. 19/2016 i.e.:

a. may re-display Electronic Information and/or Electronic Document in full according to the retention period stipulated by the Laws and Regulations;

b. can protect the availability, integrity, authenticity, confidentiality and accessibility of Electronic Information in the Administration of such Electronic Systems;

c. may operate in accordance with procedures or instructions in the Operation of the Electronic System;

d. equipped with procedures or instructions that are announced with language, information, or symbols that can be understood by the party concerned with the Operation of the Electronic System; and

e. has an ongoing mechanism for maintaining the novelty, clarity, 
and responsibility of procedures or guidelines.

The next issue is whether the recording material is original or duplicated. In response to this problem, it is necessary to audit the information system. If an information system has been audited or certified by a standard body then the proof of the tape cannot be denied and can be used directly as evidence. If the information system has not been audited then it is necessary to do an audit immediately. Such evidence shall then be subject to the legalization of a legal division and a person who has certification and specialist expertise which guarantees if the recorded tape material transferred on a CD containing microsoft power point, DVD-R, CD-R files or any other type of redirection is in accordance with originally, furthermore the evidence is recorded in the Document Transformation Report.

Definition Electronic information under Article 1 paragraph (1) Law No. 19 Year 2016 About Information and Electronic Transactions (Law on ITE) is one or a set of electronic data, including but not limited to writing, sound, drawing, maps, designs, photographs, electronic data interchange (EDI), electronic mail (e-mail), telegram, telex, telecopy or the like, letters, marks, numbers, access codes, symbols or perforations that have been processed which have meaning or can be understood by those who are able to understand them.

Furthermore, Article 5 of the Law on ITE states the validity of Electronic Information as evidence i.e.:

1) Electronic Information and/or Electronic Documents and/or prints are legal evidence;

2) Electronic Information and/or Electronic Documents and/or prints as referred to in paragraph (1) shall constitute an extension of valid evidence in accordance with applicable Law of Procedure in Indonesia;

3) Electronic Information and/or Electronic Documents shall be declared valid if using Electronic System in accordance with the provisions set forth in this Law, and;

4) The provisions concerning Electronic Information and/or Electronic Documents as referred to in paragraph (1) shall not apply to:

(a) Letters which by law shall be made in writing; and

(b) Letters and their documents which by law shall be made in the form of notarial deeds.

Regarding the requirements of an electronic information may be used as an instrument of evidence provided for in Article 6 of the ITE Law, in the case of any provision other than that provided for in Article 5 paragraph (4) which requires that any information be in writing or original form, Electronic Information and/or electronic documents are deemed valid as long as the information contained therein is accessible, displayed, guaranteed wholeness, and can be accounted for so as to describe a situation.

Article 6 of the ITE Law explains that So far, the written form is identical with the information and/or documents contained on paper alone, whereas in essence information and/or documents can be poured into any media, including electronic media. Within the scope of the electronic system, the original information with its copy is irrelevant to distinguish because the electronic system basically operates by means of duplication resulting in the original information indistinguishable from the copy.

Proof of video recording is essentially a proof in the criminal act of possession of sharp weapons, the video recording cannot stand alone as a valid 
evidence, but the video recording can be used as evidence in this case if the recording is presented in court and then required an expert forensics to explain the truth of video and the authenticity of the video presented in front of the trial so that the video recording can be used as legal evidence, that is used is expert's testimony.

\section{THE POWER OF VIDEO RECORDING AS LEGITIMATE EVIDENCE IN COURT SESSIONS}

Legitimate Proof of Evidence in the provision is contained in the applicable laws and regulations, and such evidence is obtained legally as required in the legislation. Stages of proof there are elements that play an important role, namely:

1. The elements of evidence. The prosecutor in the criminal proceedings of the criminal case is in charge of making clear an alleged crime, and the defendant is guilty on the basis of the evidence that has been collected. At the stage of proof must use valid evidence according to the law of evidence, and should not use evidence that is not regulated in legislation.

2. The evidence in the KUHAP limits the valid evidence as mentioned in Article 184 namely witness' testimony, expert's testimony, letter, indication, and defendant' testimony

3. The proofs are obtained legally and in accordance with applicable laws and regulations.

Regarding the valid evidence and how the evidence is obtained so that it has the valid evidentiary power has been described in Articles 185 to Article 189 KUHAP namely:

(1) The testimony of the witness as evidence is what is stated in court;
(2) The description of a witness alone is not sufficient to prove that the defendant is guilty.

(3) The provisions referred to in paragraph (2) shall not apply if they are not accompanied by other legal evidence.

(4) A description of several stand-alone witnesses of an event or circumstance may be used as a valid proof if the witness's statements are related to one another in such a way as to justify a particular event or circumstance.

(5) Neither opinion nor invention, derived from the results of thought alone, is not a testimony of witnesses.

(6) In judging the truth of the testimony of a witness, the Judge must be seriously concerned the statements of witnesses that are not sworn in alignment with others, are not evidence, but if the statements of a sworn witness can be used in addition to other legal evidence.

Article 187 KUHAP set letter evidence. The letter as referred to in Article 184 paragraph (1) letter c, made on oath of office or reinforced by the oath is:

a. Minutes of events and other letters in the official form prepared by the authorized or authorized public authority which contains information about the event or circumstances heard, seen or experienced by itself, accompanied by a clear reason for the information;

b. A letter made in accordance with the provisions of legislation or letters made by the officer concerning the duties and functions which are his responsibility and intended for the proof of things;

c. An explanation from an expert containing opinions based on his or 
her expertise on an officially requested situation;

d. Other letters that can only apply if they relate to other evidence.

KUHAP does not explain the evidence of records, and how to obtain and submit evidence of recording in front of the court as a valid evidence. Submission of recording evidence as valid evidence is further regulated in the ITE Law, namely how to obtain evidence of recording so that it can be filed in court and has the power of proof.

Making proof of recording as a valid evidence in a court must meet formal and material requirements. Electronic evidence in the form of electronic information and/or electronic documents and/or prints is legally recognized as evidence that may be filed in the Court. Furthermore, Article 5 paragraph (4) jo. Article 6 jo. Article 15 jo. Article 16 of the ITE Law regulates the requirements of the validity of electronic evidence, both formally and materially.

Decision of Constitutional Court No. 20/PUU-XIV/2016 has consequences that an electronic information and/or electronic document may be used as a valid evidence in court, in the event that the evidence has fulfilled the above formal and material requirements, as well as electronic information and/or electronic documents must be requests from the police, prosecutors, and/or other law enforcement agencies in order to enforce the law.

The facts of the trial reveal that JPU in the proof presenting video recordings obtained from a resident, then the video is copied to VCD-R by the next investigator presented in front of the trial and played in the trial. At first CD-R submitted trial damaged and unusual in play, then the prosecutor asked the panel of judges to give time to re-copy the video and re-copy by the JPU, then played at the next hearing. At the request of video (copied video into CD-R) by the public prosecutor, the defendant's legal advisor objected for the following reasons:

1. The evidentiary process is the process of proving whether the defendant's faults are proven or not, based on the evidence presented as required in the legislation.

2. The proofing process is no longer the process of seeking, collecting, or making evidence, but the evidence already collected in the test of whether it has the evidentiary power in the court, so that the recreation of the video by the prosecutor in the verification process is legally flawed.

3. Court proceedings of the copying event is made by an investigator who is not digital forensic so as to have no special expertise for copying, and cannot guarantee that the video copied to the $\mathrm{CD}-\mathrm{R}$ is original, so the copying process from master video to $\mathrm{CD}-\mathrm{R}$ is illegitimate, defective law, and cannot be used as valid evidence in court.

Video recordings can be used as evidence in court if supported by digital forensic experts who explain the video in accordance with the master, there is no snippet or addition of images on each frame of the video, then explain the events that occur in the video, then the expert explanation digital forensics of the video recording can be used.

\section{CONCLUSION}

Based on issues formulation, results and discussion, the authors concluded about the power of electronic video recording proof in crime possession of sharp weapons as follows:

1. KUHAP does not recognize video recording as evidence, in criminal acts concerning sharp weapons 
referred to in Law No. 12 Year 1951, referring to KUHAP as a formal law. The evidentiary system in Indonesia uses a negative evidentiary system (negatiefwettelijk) so that the judge in making a decision about whether or not a defendant is bound by the evidence determined by the judicial law and creed (conscience) of the judge. Based on the evidence, the judge believes the defendant's wrongdoing. Proof of video recording cannot stand alone as evidence but can be as a supporter of valid evidence, or supported by legal evidence as contained in article 184 KUHAP.

2. The power of evidence in the trial is whether the proposed evidence has fulfilled the element of proof both material and formal. The presented evidence has been obtained legally and meets the requirements referred to in the legislation. In order to make a video recording as evidence, it should be noted that video recording or electronic documents are considered valid as long as the information contained therein is accessible, displayed, guaranteed wholeness and accountability so as to explain a situation. Then the video recording or electronic information and/or electronic document comes from a reliable, secure and responsible Electronic System which can then re-display Electronic Information and/or Electronic Documents in full, and can protect the availability, integrity, authenticity, confidentiality and accessibility of information electronic. Fulfill any procedures as defined in the laws and regulations.

\section{NOTES}

${ }^{1}$ Rusli Muhamad, Sistem Peradilan Hukum Pidana Indonesia, UII Press, Yogyakarta. 2011, p.13

2 Andi Sofyan, Hukum Acara Pidana Suatu Pengantar, Prenada Media Group. Jakarta, 2014, p. 3.

3 Andi Sofyan and Abd. Asis, Hukum Acara Pidana Suatu Pengantar, Prenada Media Group. Jakarta. 2014, p. 3

${ }^{4}$ Bambang Waluyo, Manajemen Penelitian, Sinar Grafika, Jakarta, 2002, p. 67.

5 Yahya Harahap, Pembahasan Permasalahan dan Penerapan KUHAP, Sinar Grafika, Jakarta, 2008, p. 273.

${ }^{6}$ Martiman Prodjohamidjojo, Pembahasan Hukum Acara Pidana Dalam Teori dan Praktek, Pradnya Paramita, Jakarta, 1998, p. 133.

\section{REFERENCES}

Andi Sofyan. 2014. Hukum Acara Pidana Suatu Pengantar. Prenada Media Group. Jakarta.

Bambang Waluyo. 2002. Manajemen Penelitian. Sinar Grafika, Jakarta.

C. Djisman Samosir, 2013. Segenggam Tentang Hukum Acara Pidana. Nuansa Aulia. Bandung

Chandra M. Hamzah. 2014. Penjelasan Hukum Mengenai Bukti Permulaan yang Cukup. Pusat Studi Hukum dan Kebijakan Indonesia (PSHK) UI, Jakarta.

Mertiman Prodjohamidjojo. 1998. Pembahasan Hukum Acara Pidana Dalam Teori dan Praktek., Pradnya Paramita, Jakarta.

Rusli Muhamad. 2011. Sistem Peradilan Hukum Pidana .Indonesia, UII Press, Yogyakarta.

R. Soeparmono. 2015. Prapradilan dan Penggabungan Perkara Gugatan Ganti Kerugian dalam KUHP. Mandar Maju, Bandung.

Soejonodan H. Abdurahman. 2003. Metode Penelitian Hukum. Rineka Cipta, Jakarta.

Yahya Harahap. 2008. Pembahasan Permasalahan dan Penerapan KUHAP. Sinar Grafika, Jakarta. 
Syawal Abdulajid

Faculty of Law

Universitas Khairun

Indonesia

Email: univkhairun_tte@yahoo.co.id 